\title{
Eco-Marine-Tourism Development Towards The Renewal of Coastal Communities in Gerokgak District, Bali
}

\author{
Cening Kardi and I Wayan Wiasta
}

University of Mahasaraswati Denpasar

Corresponding Author: lovelycening@unmas.ac.id

\section{ARTICLE INFO}

Received

3 December 2019

Accepted

15 February 2020

Available online

31 March 2020

\section{ABSTRACT}

The environmentally-aware marine tourism research aimed: (1) to analyze the geographical indication for grouper products in Gerokgak district; (2) to analyze the management efforts to guard coastal and marine healthy in the form of customary rule; and (3) to formulate the model for development of Gerokgak coastal eco-marine-tourism. The research method used survey, focus group discussion and laboratory examination. The Grouper aquaculture products both seeds and fishes of Cantang cultivar on the coast of Gerokgak district have been excellent due to the appropriate geographic factors, quality of coastal and marine waters, substrate condition of the seabed and climate and the unique culture of the local community which is identified as Nyegare-Gunung cultivation. The Geographical Indications for Cantang grouper potentially to provide opportunities for fishery producers to consolidate and increase prices on the market. The reputation built around the Geographical Indications can strengthen the product position in the domestic and international markets as well as to penetrate the new export market. The development of eco-marinetourism in Gerokgak district should control the degradation of environmental quality for grouper aquaculture by creating customary rules of Awig Awig and Subak for coastal villages, and implementation to achieve rationality in utilizing coastal and marine resources harmoniously with the system of values in tradition, religion, aspiration, and culture of the local communities. To keep the reputation of grouper products towards a certification that the product possesses certain qualities, is made according to local integrated marinculture methods, due to Gerokgak's geographical origin. They should do structuring and developing Bangsal Beach for centre destination to access the sea cage cultivations, as well as Batu Agung Beach as center access to hatchery objects. Marketing tour packages of the activities, products, and landscapes of the grouper marinculture in which the setting up Eco-marine-tourism management should follow open/spontaneous type with the purpose: to grow region merging with the structure of life, both space and patterns in accordance with the local community or community-based tourism.

Keywords: Eco-marine-tourism, Grouper, Coastal, Geographical indication 


\section{INTRODUCTION}

The development of the national economy and particularly Bali, one of which can be pursued through the utilization of coastal and marine resources for developing of marinculture businesses. Bali is an area that is very dense with the life of traditions, religion, aspirations and culture based on Tri Bhuwana / Three Worlds: Bhur, Bhuwah, Swaha or physical nature, mind nature, and transcendental nature, which is therefore to make Bali become the main destination for the world tourism. Bali is located at the confluence of the world's coral triangle. Bali's marine waters are homegrown to various types of marine life that not only provide protein and minerals for people's lives, but also become a main pillar of culture-based tourism development.

Determination of the coast from Gerokgak village to Sumberkima village in Gerokgak district by the Buleleng Regency Government as a center marine aquaculture area and is part of the development area of Batu Ampar Tourism in West Buleleng, on the one hand, it provides a very strategic opportunity for the development of marine aquaculture. However, on the other hand, it is suspected to provide ecological pressure on the ecosystem, coastal and marine resources. In this manner, it is necessary to know the http://ojs.unud.ac.id/index.php/eot degradation of the environmental quality of marine aquaculture.

The Grouper aquaculture products (both seeds and fishes) on the coast of Gerokgak district have been excellent due to the appropriate geographic factors, quality of coastal and marine waters, substrate condition of the seabed and climate and the unique culture of the local community. However, the national and international trade in grouper products has not had a certificate of Geographical Indications yet, even though the legal protection of Geographical Indications can protect grouper fish products from violations of product reputation. In addition, Geographical Indications can encourage and provide opportunities for producers to jointly maintain and improve product quality, consolidate or even increase prices on the market. Furthermore, the reputation built around the Geographical Indications of Gerokgak district can be an important marketing tool to strengthen the product position in the domestic and international markets as well as to penetrate the new export market.

The exploration of Geographical Indications of grouper aquaculture products must be supported with integrated and sustainable management of coastal areas in Gerokgak district, which integrates every interest in balance (proportionality) between ecological 
dimensions, social dimensions, LITERATURE REVIEW

intersectoral, scientific disciplines and all stakeholders of the coastal area. In this case, it is necessary to stipulate management regulations in the form of awig-awig (customary rule) of the coastal communities in Gerokgak district. Furthermore, the development of ecomarine-tourism destinations from the activities and landscape of grouper farming will be able to build an integrated and coordinated activity system to develop tourism sector as well as aquaculture sector while maintaining environmental sustainability and increasing wider positive social impacts and values for coastal communities in the Gerokgak district. The problem then is how to develop the Gerokgak Coastal Eco-marine-tourism?

\section{Research objectives}

1. to analyze the Geographical Indication for grouper products in Gerokgak district;

2. to analyze the management efforts to guard coastal and marine healthy in the form of customary rule; and

3. to formulate the model for development of Gerokgak Coastal Eco-marine-tourism.

Bali relies heavily on the development of sustainable tourism. On the other hand, the rapid development of tourism in Bali has brought tremendous breaking energy which has caused degradation of the natural /agricultural/aquatic environment quality and affects structural changes to Balinese society and culture significantly. Bali often has to face difficult choices, whether developing tourism at the expense of agriculture and the environment or maintaining agriculture and environment by limiting tourism development. In accordance with the goals of SDGs 2030, that development must always be oriented towards a balance between economic development, social improvement and environmental preservation. The best resolution is rather developing tourism sector without degrading agriculture and environment (Vipriyanti, 2012).

One alternative that is in this combination is the development of ecoagro-tourism to agricultural areas both on land, coast, and sea. The eco-agro-tourism which specifically uses marine/sea areas here is the concept of eco-marinetourism. Eco-marine-tourism aims to provide marincultural value-added in the broadest sense and environmentally sound, as well as to develop tourism through adjusting and marketing tour e-ISSN: 2407-392X. p-ISSN: 2541-0857 
packages of the activities, products, and landscapes of the marincultural cultivation (Kardi, 2019).

Utilization of agricultural activities that rely on coastal and marine waters or marine aquaculture which is used as an agrotourism destination in Bali is very rare. Such marine aquaculture is the development of various types of reef fish with a superior commodity, namely grouper. These grouper aquaculture businesses have been carried out en masse in the West Buleleng area (Gerokgak district) especially along the coastal waters of Gerokgak village, Sanggalangit, Penyabangan Musi and Banyu Poh. (hatchery activities), and the marine waters of Sumberkima village (fish enlargement activities in floating net cages / KJA). Grouper cultivation should be developed because of some of its economic advantages, besides being suspected to reduce damage to coral reef ecosystems. This effort is growing because the production process uses more of the existing coastal and marine resources, and uses large local components, while the product has potential to export (Hanafi et al., 2005).

\section{METHODOLOGY}

The assessment of parameters of environmental health for marinculture and the management efforts to keep the health were carried out at twelve observation stations on along the coast of Gerokgak district. Health parameters aquatic environments for aquaculture (physical, chemical and biological) as well as the tools used to measure referred to the APHA (1992). The mapping of Geographical Indications for grouper products in Gerokgak district was done with a survey to 30 hatchery firms, and 15 grouper KJA firms. Primary data were collected with the survey to chemical and biological characteristics (laboratory test) on six grouper seeds and six fishes product from KJA as well as characteristics of the production process. To formulate Gerokgak Coastal Eco-marine-tourism was done with coastal communities involvement in a focus group discussion (FGD) in Gerokgak and Sumberkima village. Tabulation of data and descriptive statistical analysis were used in generating the finding. 


\section{RESULTS AND DISCUSSION}

\section{The profile of fisheries cultivation business related to Grouper Geographical Indication}

The potency of marinculture for ecomarine-tourism in Gerokgak district is as follows. Grouper cultivation include three stages, namely: (1) hatchery that produces juveniles of grouper with a size of $3.0-4.0$ $\mathrm{cm}$; (2) nurseries that produce grouper yuwana fishes with a size $7.0-10.0 \mathrm{~cm}$; and (3) ranching fishes in floating net /KJA cages in the sea that produce grouper consumption size. Each of the three stages of production can be turned into an independent business (industry), but the most potential hatchery and nursery activities and technology can be utilized by the coastal communities in Gerokgak district in an effort to increase family income. Hatchery and fishes breeding are carried out en masse along coastal waters in the villages of Gerokgak, Sanggalangit, Musi, Penyabangan and Banyu Poh, while fish ranching activities in floating net cages / KJA are concentrated in the waters of Sumberkima Bay.

The Cluster analysis at the site level is used to determine the five main types of coral communities that are related to wave level, current - upwelling, substrate type and geographic location. The coastal area of Gerokgak district is included in the http://ojs.unud.ac.id/index.php/eot relatively sheltered coral community where the waves are smashed, currents upwelling, substrate type and geographic location are ideal for aquaculture (marinculture activities).

The potential area of the coastal in Gerokgak district for sea fish hatchery cultivation is 120 hectares, but only 30 hectares have been utilized. This hatchery area has an altitude of $0-10 \mathrm{~m}$ above sea level, the beach is not too plane with not muddy seabed condition. The coastal waters are clean and not muddy, with sea water salinity of 32-34 ppt. Seawater can be pumped for a minimum of 20 hours per day. Freshwater sources are available with a maximum salinity of $5 \mathrm{ppt}$ through the Gerokgak Regional Drinking Water Company. All hatchery business locations have easy accessibility, and are affordable by car. The location designation is in accordance with the Regional / Regional Spatial Planning (RUTRD / RUTRW). All of these natural resource characteristics are ideal for developing a marine fish hatchery

There are 72 venture grouper hatcheries along the coast of Gerokgak with a total area of 1180 larvae tanks. Besides larvae tanks, a grouper hatchery also needs plankton tanks and rotifer tanks as tanks for natural food production for grouper larvaes. The overall grouper hatchery firms absorb labor force of about 500 people remained and 700 seasonal 
workers. However, at certain times drought can decrease the quality of seawater in the area around the inlet and outlet which result in the death of natural foods (plankton, rotifer) larvae and fish en masse. Therefore it is very important/ urgent to check the quality of the physical, chemical and biological of the seawater around the inlet and outlet of the hatcheries. The grouper hatchery activity which is a biological application of the food chain in the growing larvaes to be juveniles/seeds (size $3-5 \mathrm{~cm}$ ) has attraction as an object for education eco-marinetourism.

Some species of grouper fish that have been successful and commonly produced by the local farmers in Gerokgak, namely: Tiger grouper (Epinephelus fuscoguttatus), Rat grouper (Cromileptes altivelis). In line with development in spawning and grouper hatchery technology, the backyard hatchery community in Gerokgak District began producing Cantang hybrid grouper seeds, namely the crossing between Tiger grouper (Ephinepelus fuscoguttatus, Forsskal 1775) and Naga / Kertang grouper (Ephinepelus lanceolatus, Bloch, 1790). The grouper hybridization is strived to achieve the objectives: (1) to produce groupers with fast growth; (2) improvement in the quality of grouper meat; (3) control of the grouper malehttp://ojs.unud.ac.id/index.php/eot female ratio; (4) increase grouper resistance to disease; and (5) improvement of fish tolerance to extreme micro and macro environmental conditions. In the development of grouper hatchery business, it turns out that the most optimal Cantang hybrid grouper seed meets the grouper development goal. This is because Cantang groupers have very fast growth in floating net cages, with a stocking size of 8-10 cm within 7 months has reached consumption size, while other types of grouper fish need the fastest time of 12 months. The supporting geographical environmental factors as well as natural and human factors in cultivating grouper aquaculture in the coast and sea of Gerokgak district, which is a single entity, has had an influence on the quality or characteristics of the Cantang hybrid grouper produced. It is very strategic then to propose certification on The Geographical Indications for Gerokgak's Cantang grouper.

The potential sea waters of Sumberkima bay for ranching groupers in floating cage/KJA is 1480 ha, but yet there are only 27 KJA firms. Their total fishponds $(3 \times 3 \mathrm{~m})$ are 3864 units and apply only about 100 ha waters of Sumberkima bay $(6,8 \%)$. The average investment capital per fishpond is $R p$ $4,000,000.00$, and working capital is $\mathrm{Rp}$ $6,000,000.00$, so the average account for 
running a fishpond is $\mathrm{Rp} 10,000,000.00$. On average for running 100 fishponds employs 30 workers, so the whole sea cage farms in Sumberkima bay absorbs 1160 workers. The maximum production for the whole grouper KJA in Sumberkima bay is about 483 ton per cycle production.

\section{The mapping of Geographical Indication for grouper products in Gerokgak district}

The name of proposed geographical indication to the government (Kementerian Hukum dan HAM RI) is Geographical Indication Certificate for Gerokgak's Cantang Grouper. The product will be protected by this Certificate is Cantang Grouper in the form of seed or juvenile. The detail and qualities of the product are as follows.

$\checkmark$ Juvenile D40 (40 days old, calculated from the time the eggs hatched with a total length of $2.8-3.2 \mathrm{~cm}$ ); Survival rate $\geq 15 \%$; Uniformity $\geq 80 \%$ )

$\checkmark$ Juvenile D50 (50 days old, calculated from the time the eggs hatched with a total length of $4.5-5.5 \mathrm{~cm}$; Survival rate $\geq 80 \%$; Uniformity $\geq 80 \%$ )

$\checkmark$ Seed D60 (60 days old, calculated from the time the eggs hatched with a total length of $6.5-7.5 \mathrm{~cm}$; Survival rate $\geq 80 \%$; Uniformity $\geq 80 \%$ ) $\checkmark$ Seed D75 (75 days old, calculated from the time the eggs hatched with a total length of $9.0-11.0 \mathrm{~cm}$; Survival rate $\geq 80 \%$; Uniformity $\geq 80 \%$ ).

$\checkmark$ Body shape is round and perfect.

$\checkmark$ Body color is blackish gray

$\checkmark$ Mouth shape is wide, superior (lower lip is longer than the upper lip).

$\checkmark$ Health is complete limbs, not morphologically deformed, and free of disease (viruses, fungal, bacteria and parasites).

$\checkmark$ Movement is normal swimming.

$\checkmark$ Response to given feed is positive

The substantive mapping of the geographical indications for Cantang groupers can be described as follows. The applicant for a certificate of geographical indication is the Community for Protecting Geographical Indications of Gerokgak's Grouper. The quality control in the field is carried out by the groups of grouper cultivator. The fish delivery is accompanied by complete inspection from the Ngurah Rai Fisheries Quarantine Center. The farmers as Producer have made complete records of investments, production facilities, labor, production, product shipments and planning for further production activities. The dynamics of regular farmer meetings at least once every three months discussing updates on production techniques, control of fish pests 
and diseases, joint procurement of production facilities, and joint marketing. The list of farmer groups from upstream to downstream agribusiness in grouper aquaculture is complete. The capability of farmers in the production activities as well as the management of inputs and production is quite well established.

Environmentally friendly cultivation is applied both to grouper rearing activities in cages and to hatcheries. They use combination of natural food and pellets plus enzymes that enrich feed and vitamins. The farmers use application of controlled biosecurity and integrated marinculture. Post-harvest ability: groupers are sent in a fresh condition of life using a plastic bag that is given enough oxygen and the fishes are fasted before being packaged. The delivery of grouper size consumption uses an aquarium that is transported to the Hong Kong ship berth. The grouper quality test includes: physical quality test, chemical and biological pollutant content, as well as fish taste test, unique taste and flavor elasticity. Human recources development conducted by government, private sector, NGOs and experienced farmers.

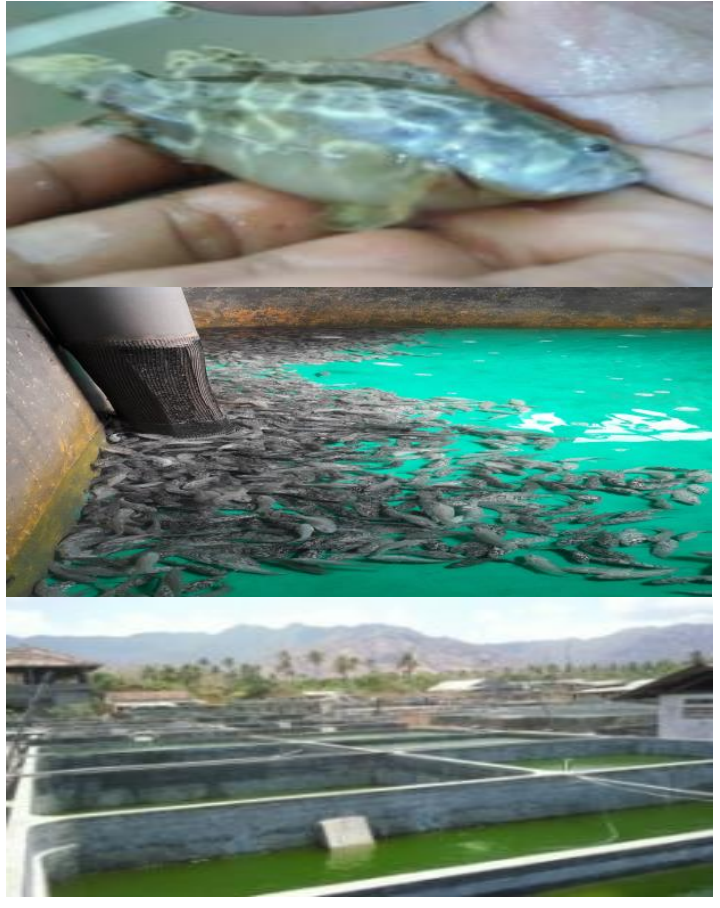

Figure 1. Photograph of Cantang Groupers in the form of seed or juvenile

The result of laboratory test on grouper products indicates that the quality of seeds and fishes were good and healthy and did not contain harmful pollutants (see Table 1 and Table 2). The quality of coastal and marine waters, the substrate condition of the seabed and climate and the local unique culture (Nyegare-Gunung cultivation) have been the factors of good grouper aquaculture products. The meaning of Nyegare-Gunung cultivation: the all life activities carried out on land/Gunung will have an impact on the sea/Segare; so also what is done in the sea will have an impact to people on land. So that Segare and Gunung cultivation 
management must be integrated which prioritizes health and sustainability).

Table 1 . The result of health laboratory test on 6 grouper fishes

\begin{tabular}{|c|c|c|c|c|}
\hline & Parameter & $\begin{array}{c}\text { Test } \\
\text { result } \\
\text { (average) }\end{array}$ & $\begin{array}{c}\text { Degrees } \\
\text { of } \\
\text { Variance } \\
(\%)\end{array}$ & $\begin{array}{c}\text { Health } \\
\text { Standard }\end{array}$ \\
\hline \multicolumn{5}{|c|}{ Microbiology test } \\
\hline 1) & $\begin{array}{l}\text { Escherichia } \\
\text { colli }\end{array}$ & $<3$ & 0 & $<3$ \\
\hline 2) & Salmonella & Negative & 0 & Negative \\
\hline 3) & Parasite & 0 & 0 & 0 \\
\hline 4) & $\begin{array}{l}\text { Coliform } \\
\text { Chemical test }\end{array}$ & $<3$ & 0 & $<3$ \\
\hline 1) & Histamine & 33.18 & 24.41 & Max 100 \\
\hline 2) & TVB & 9.48 & 12.28 & Max 25 \\
\hline 3) & TMA & 3.73 & 35.09 & - \\
\hline 4) & Formaldehide & Negative & 0 & Negative \\
\hline 5) & Plumbum & Negative & 0 & Negative \\
\hline 6) & Mercury & Negative & 0 & Negative \\
\hline 7) & Cadmium & Negative & 0 & Negative \\
\hline
\end{tabular}

The all of grouper production process, from management of broodstock, hatchery, nursery, and KJA cultivation follow well biosecurity those are indicated by high survival rate of the hatcheries production (in average of $36 \%$ ) and the KJA production (in average of $88 \%$ ). The specific policy for sustainable development of grouper marinculture that encompasses, seed, feed, investment, environment, technology and trade in Gerokgak district have been well done and well placed. The private sector have contributed significantly to the development of grouper marinculture, either in hatchery or in grow-out farms. Private corporations have invested processing, farming equipment and supplies. The all of above excellences which figuring the profile of fine integrated grouper marinculture are indeed to support the applying Certificate of Geographical Indication for Gerokgak's grouper and then supports feasible ecomarine-tourism.

Table 2. The result of health laboratory test on 6 grouper seeds

\begin{tabular}{|c|c|c|c|c|}
\hline & Parameter & $\begin{array}{c}\text { Test } \\
\text { result } \\
\text { (average) }\end{array}$ & $\begin{array}{c}\text { Degrees } \\
\text { of } \\
\text { Variance } \\
(\%)\end{array}$ & $\begin{array}{c}\text { Health } \\
\text { Standard }\end{array}$ \\
\hline \multicolumn{5}{|c|}{ Microbiology test } \\
\hline 1) & $\begin{array}{l}\text { Escherichia } \\
\text { colli }\end{array}$ & $<3$ & 0 & $<3$ \\
\hline 2) & Salmonella & Negative & 0 & Negative \\
\hline 3) & Parasite & 0 & 0 & 0 \\
\hline 4) & $\begin{array}{l}\text { Coliform } \\
\text { Chemical test }\end{array}$ & $<3$ & 0 & $<3$ \\
\hline 1) & Histamine & 6.96 & 13.97 & Max 100 \\
\hline 2) & TVB & 4.77 & 19.98 & $\operatorname{Max} 25$ \\
\hline 3) & TMA & 0.00 & 0.00 & - \\
\hline 4) & Formaldehide & Negative & 0 & Negative \\
\hline 5) & Plumbum & Negative & 0 & Negative \\
\hline 6) & Mercury & Negative & 0 & Negative \\
\hline 7) & Cadmium & Negative & 0 & Negative \\
\hline
\end{tabular}

The environmental health of sea waters for aquaculture and the management efforts

Fluctuations of the tide in Sumberkima bay are considered good enough for aquaculture: ranching fishes or grouper $\mathrm{KJA}$, brackish water or ponds, due to the maximum tidal range only reaches a height of $2 \mathrm{~m}$. Seawater quality parameters, namely nitrate (NO3) and phosphate (PO4) in seawater of 0.0261- 0.0599 ppm and $0.055-0.094 \mathrm{ppm}$, although they do e-ISSN: 2407-392X. p-ISSN: 2541-0857 
not cause problems in aquaculture activities, but they have been in category exceed the quality standards of sea water for life marine biota $(<0.008 \mathrm{ppm}$ and $<0015 \mathrm{ppm}$ ) according to the Decree of the Minister of Environment No. 51 the year 2004. These are caused by the high production of domestic waste from aquaculture activities in marine waters. As for other chemical parameters: $\mathrm{pH}, \mathrm{DO}$, BOD, nitrite, and ammonia are still in the category of safe and healthy for marine life. The physical quality of seawater: temperature, TSS, salinity and texture of the base substrate are within the normal range for marine biota (see Table 3). Macrozoobenthos and plankton diversity index (2.18 and 2.38) still exceed 2.00 signify marine waters is not polluted and healthy for marine aquaculture activities. Macrozoobenthos and plankton dominance index $(0.21$ and 0.15$)$ of less than 0.40 indicate partial dominance macrozoobenthos and low plankton and signaling healthy marine water for marine aquaculture activities.

Waste marinculture excessive will increase the content of ammonia, nitrite, nitrate, and phosphate in the water, so it can reduce productivity and species composition of phytoplankton and zooplankton and makes dominance of certain species that are not expected in the marine aquaculture activities (Hanafi et http://ojs.unud.ac.id/index.php/eot al., 2008). The impact on the marine environment that may result from the mass cultivation of hatcheries and the KJA is either: a) residual waste pelleted feed and chemicals, drugs of tubs, ponds or KJA; and b) genetic pollution, as well as the transfer of diseases and parasites of fishes. The degree of impact is highly dependent on the capacity of aquaculture, farmed fish species, the density of the stock, the type of artificial feed, hydrographic of the location of cultivation and maintenance methods (Jennings et al., 2001).

Table 3. Parameter of marine water health for aquaculture in Gerokgak district

\begin{tabular}{|c|c|c|c|c|}
\hline No & Parameter & Observation & \multicolumn{2}{|c|}{$\begin{array}{l}\text { Quality standar for biota } \\
\text { or cultivation }\end{array}$} \\
\hline & \multicolumn{4}{|l|}{ Physical } \\
\hline 1 & Temperature & $28.2-30.0{ }^{\circ} \mathrm{C}$ & \multicolumn{2}{|c|}{$28.0-32.0^{\circ} \mathrm{C}$} \\
\hline 2 & Brightness & $4.8-9.5 \mathrm{~m}$ & \multicolumn{2}{|l|}{$>3 \mathrm{~m}$} \\
\hline 3 & $\begin{array}{l}\text { Suspended solid } \\
\text { (TSS) }\end{array}$ & $\begin{array}{l}0.007-0.015 \\
\text { ppm }\end{array}$ & \multicolumn{2}{|l|}{$<80.00 \mathrm{ppm}$} \\
\hline 4 & $\begin{array}{l}\text { Seabed substrate } \\
\text { Texture }\end{array}$ & $85.2-95.6 \%$ & \multicolumn{2}{|l|}{-} \\
\hline & Chemical & & \\
\hline 1 & $\mathrm{pH}$ & $8.14-8.36$ & $7.00-8.50$ & \\
\hline 2 & Salinity & $33.3-34.8 \mathrm{ppt}$ & \multicolumn{2}{|l|}{$33-35 \mathrm{ppt}$} \\
\hline 3 & DO & $6.50-8.11 \mathrm{ppm}$ & \multicolumn{2}{|l|}{$>5 \mathrm{ppm}$} \\
\hline 5 & $\mathrm{NO}_{3}$ & $\begin{array}{l}0.0261-0.0599 \\
\text { ppm }\end{array}$ & \multicolumn{2}{|c|}{$<0.008 \mathrm{ppm}$} \\
\hline 6 & $\mathrm{NO}_{2}$ & $\begin{array}{l}0.031-0.059 \\
\text { ppm }\end{array}$ & \multicolumn{2}{|c|}{-} \\
\hline 7 & $\mathrm{NH}_{3}$ & $\begin{array}{l}0.010-0.039 \\
\text { ppm }\end{array}$ & \multicolumn{2}{|c|}{$<0.300 \mathrm{ppm}$} \\
\hline 8 & $\mathrm{PO}_{4}$ & $\begin{array}{l}0.055-0.094 \\
\mathrm{ppm}\end{array}$ & \multicolumn{2}{|c|}{$<0.015 \mathrm{ppm}$} \\
\hline 9 & $\mathrm{BOD}_{5}$ & $2.10-8.74 \mathrm{ppm}$ & \multicolumn{2}{|l|}{$<20 \mathrm{ppm}$} \\
\hline \multirow[t]{2}{*}{10} & Heavy metals & \multicolumn{3}{|c|}{$\begin{array}{l}\text { Cd 1.36-5.08 ppm; Cu 3.04-42.66 ppm; Pb } \\
\text { 1.97-23.67 ppm; Mn 12.01-72.74 ppm; Zn } \\
\text { 3.4-44.25 ppm; Ni 2.11-37.66 ppm; Hg } \\
0.00\end{array}$} \\
\hline & Biological & $\begin{array}{l}\text { Index of } \\
\text { diversity }\end{array}$ & $\begin{array}{l}\text { Index of } \\
\text { uniformity }\end{array}$ & $\begin{array}{l}\text { Domination } \\
\text { index }\end{array}$ \\
\hline 1 & Macrozoobenthos & 2.18 & 0.59 & 0.21 \\
\hline 2 & Plankton & 2.38 & 0.68 & 0.15 \\
\hline
\end{tabular}


The grouper aquaculture in Gerokgak most $(85 \%)$ rely on natural feed (trash fishes, plankton, rotifers, copepods, rebon, and artemia). They do not require large quantities of pellets or other artificial protein feed. Therefore the environmental pollution of marine waters can be included that it is very low. The results of this study indicate that the phenomenon of environmental degradation of marinculture in Gerokgak district has not occurred yet, but continuously efforts to control and anticipate it should be done as to achieve integrated marinculture. As was promoted by Soto, 2009 that integrated marinculture was a mitigation approach against the excess nutrients / organic matter generated by intensive aquaculture activities, particularly in marine waters. The efforts to control and anticipation should be as follows.

a. In order to immediately do layout arrangement of a sewage treatment system in shrimp ponds, cultivation of pearl shells and other aquaculture, so the aquaculture activities conducted in this area do not cause a decrease in the quality of the environment.

b. The service agencies in the village should do more intensive in issuing aquaculture business licenses and restrictions when it exceeds the carrying capacity of land as well as fostering the importance of the http://ojs.unud.ac.id/index.php/eot environment. One of them by creating a customary village regulation (Awig Awig and Subak institution for coastal villages).

c. In the exercise of aquaculture in ponds should improve efficiency in feeding and fertilizing, restrictions on stocking densities, sewer arrangement and when there are outbreaks do sterilization and neutralization of the water before being discharged it into waterways.

d. For KJA aquaculture, pearl cultivations, shrimp ponds must do monitoring and controlling of diseases on a regular basis and environmentally friendly, countermeasures simultaneously in case of disease outbreaks to the termination of the disease cycle.

e. To avoid double fertilization organic sediments under floating net cages and pearl farming, do a safe distance between the placement of the unit of cages and cages undergo rotational placement locations for a time period to allow the decomposition of cages organic waste naturally.

f. Need to restructure seriously to timber port and fishing boats, as well as building restrictions on the coastal border, the arrangement of cleanliness and sanitation in harbour areas and 
township residents to mitigate the negative impacts on the environment.

g. Need to develop and to preserve mangroves which starting to appear any damage due to illegal logging, land clearing ponds and the onslaught of the waves.

\section{The formulation to Gerokgak Coastal Eco-marine-tourism}

The ranching in Sumberkima bay (mainly grouper sea cage farms) with its emerged surrounding landscape as well as the all along seaside hatchery farms in Gerokgak district are really good-looking and attractive destinations for Ecomarine-tourism (see Figure 2). These potential destinations can be developed for establishing a pack of education, food and recreation marintourism. There are some other factors (can be beautiful attraction looks for tourists) that contributed to the success of the coastal eco-marine-tourism program. They are the uniqueness of Sumberkima values and cultures founded in harmonious pluralism on tradition, religion, and aspiration (Moslem, Hinduism, Christian as well as Balinese, Mandarnese, Maduranese, and Javanese). Some traditional heritage temples of Pulaki, Prapat Agung, Segare Rupek and Gili Kencana for religious tourism can be connected to the ecomarine-tourism.

The sites of all hatchery and KJA firms have good accessibility (can be reached by car). On the focus group discussion (FGD) in Sumberkima village which attended by 45 representatives of all coastal social stratum in Gerokgak district, it was concluded that the forum was in agreement to develop and to foster Ecomarine-tourism in Gerokgak district. Especially they required a center for accessing the object of grouper KJA farms at Bangsal beach (one of the beaches in Sumberkima bay). Furthermore, all of the representatives expected the marintourism development a large amount for improving the coastal farmers (small fishing groups) own earnings. The survey to 30 broodstock/hatchery farmers indicated their strong holding up to the development program of eco-marine-tourism, as well as they, were willing to arrange their backyard hatchery to be a destination for education Eco-marine-tourism. The central access for this destination should be at Batu Agung beach. 


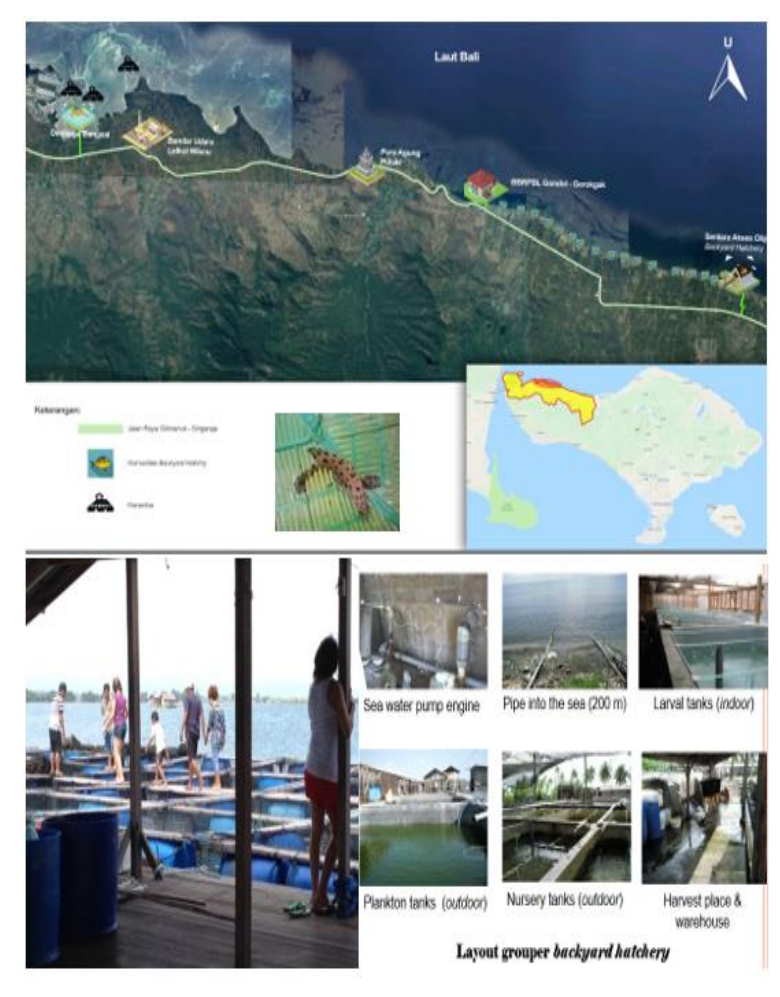

Figure 2. The landscape map of Gerokgak coastal eco-marine-tourism

The vision and mission of the Gerokgak coastal Eco-marine-tourism are "We would like to provide a sustainable future for the people in coastal communities in Gerokgak district, instead of leaving to travel to the cities for employment, they will have a beneficial future here. Finally, the safeguarding to marinculture is of paramount importance to sustainable integrated marinculture and dealing out it to the tourism sector must be the coastal communities way. By returning to prudent tradition-religion-aspirationculture values and practices in marine economic activities, we will restore the earth to a point before damages \& disarray threatened our coastal existence. These are what we would like to share with the world". These below measures should be done to realize the above vision-mission.

a. To develop a website with dealing vision and mission: "integrated grouper marinculture arranged with community economic development through eco-marine-tourism. Contact destination should be in Sumberkima village". website in the relation is www.omnibaliagrotourism.com.

Establishing a center for accessing the sea cage farms at Bangsal beach. Some facilities should be there at this center: a simple seaport equipped with a small bridge connecting the mainland to the port; parking area; some food and drink and souvenirs stands; and a pair of bathrooms-toilets.

b. The setting up eco-marine-tourism management should follow open/spontaneous type (Ross and Glenn, 2006) with a purpose: growing region merging with the structure of life, both space and patterns in accordance with the local community (community-based tourism). Distribution of the revenue generated from visitors must be in a large amount for local residents, but the negative impacts (declining their local genius/wisdom) may quickly spread into the local population. The e-ISSN: 2407-392X. p-ISSN: 2541-0857 
negative impacts should be tightly of customary villages (desa adat) and customary hamlets (banjar adat) in Gerokgak district.

The basic premise of ecotourism is simple, and its potential extends well beyond tropical systems. Tourists pay to experience nature in a manner that respects the local culture and environment. The local economy and culture benefit, creating an enduring incentive for the locals to maintain the supply of tourists via natural resource conservation (Honey, 2008). Therefore The Gerokgak coastal ecomarine-tourism development should adhere to three basic principles of sustainable development: (i) conserving natural areas; (ii) soothing/educating visitors; and (iii) benefiting the local population. The Model for Development of Gerokgak Coastal Eco-marine-tourism can be seen in Figure 3. controlled through the involvement

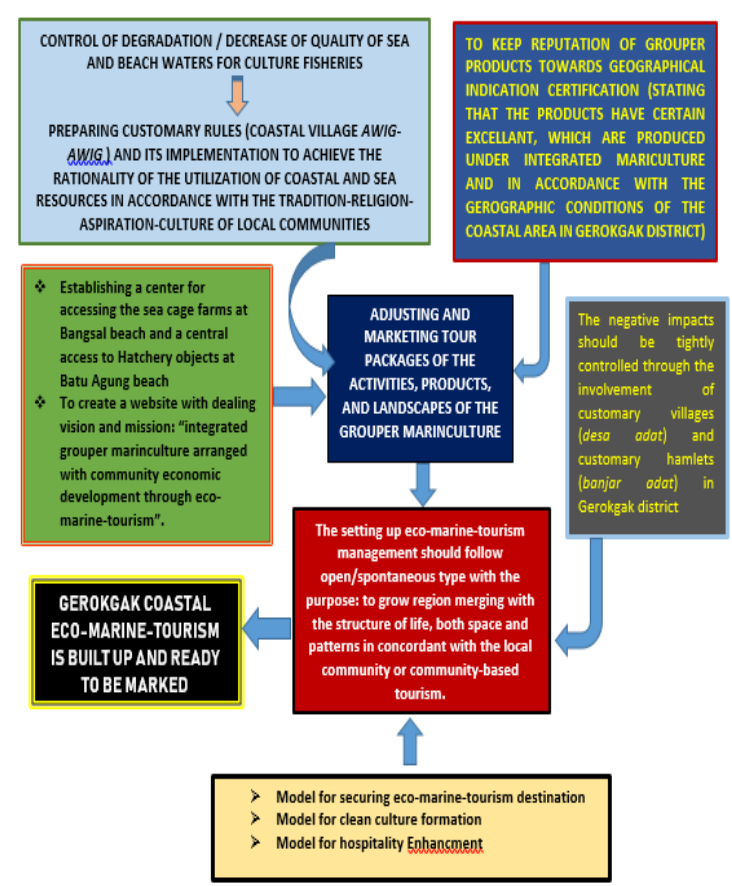

Figure 3. Model for development of Gerokgak Coastal Eco-marine-tourism

\section{CONCLUSION}

Model for developing Coastal Ecomarine-tourism in Gerokgak district can be described as follows.

1. Control to degradation of environmental quality for grouper aquaculture by creating customary rules (Awig Awig and Subak for coastal villages) and implementation to achieve rationality in utilizing coastal and marine resources harmoniously with the system of values in tradition, religion, aspiration, and culture of the local communities.

2. To keep the reputation of grouper products towards geographical indication (may act as a certification 
that the product possesses certain qualities, is made according to local integrated marinculture methods, due to Gerokgak's geographical origin). Packaging and marketing tour packages of the activities, products, and landscapes of the grouper marinculture in which the setting up eco-marine-tourism management should follow open/spontaneous type with the purpose: growing region merging with the structure of life, both space and patterns in accordance with the local community (community-based tourism).

3. The negative impacts those may occur to people in the community should be tightly controlled through the involvement of customary villages (desa adat) and customary hamlets (banjar adat) in Gerokgak district.

\section{Acknowledgments}

The research was funded by Competition Research Grant Year 2018-2019. It was a research program from Directorate General of Strengthening Research and Development in Jakarta. Among those who had been especially helpful as technical assistance for this research were Husama Umar, Ketut Suparto, I Ketut Sutari, and Iwan Setiawan, the authors expressed thanks in recognition of their services.
APHA, 1992. Standard Methods for The Examination of Water and Waste Water. Washington DC., USA: APHA, AWWA.

Hanafi, A., Awal Subandar, dan Kris Sunarto, 2005. Urgensi Kajian Lingkungan dan Tata Ruang Kawasan Pesisir dalam Mendukung Pengembangan Budidaya Kerapu Berkelanjutan. Jakarta: Pusat Pengkajian dan Penerapan Teknologi Budidaya Pertanian, BPPT.

Hanafi, A., Syahidah, dan Andriyanto, 2008. Kajian Daya Dukung Lahan Teluk Pegametan untuk Budidaya Ikan Kerapu dalam Karamba Jaring Apung.

Gerokgak: BBRPBL Gondol.

Honey, M., 2008. Ecotourism and Sustainable Development: Who Owns Paradise? Washington, DC: Island Press.

Jennings, S., Kaiser, M.J., Reynolds, J.D., 2001. Marine Fisheries Ecology. Victoria: Blackwell.

Ross and F. Glenn, 2006. Psychology of Tourism. Jakarta: Yayasan Obor Indonesia.

Soto, D., 2009. Integrated Marinculture: a global review. FAO Fisheries and Aquaculture Technical Paper. No. 529. Rome: FAO. 2009.

Vipriyanti, N.U., 2012. Pengembangan Jalur Agrowisata Kaje-Kelod di Buleleng Barat-Bali. Jurnal Agrimeta Vol 2 No. 03. 